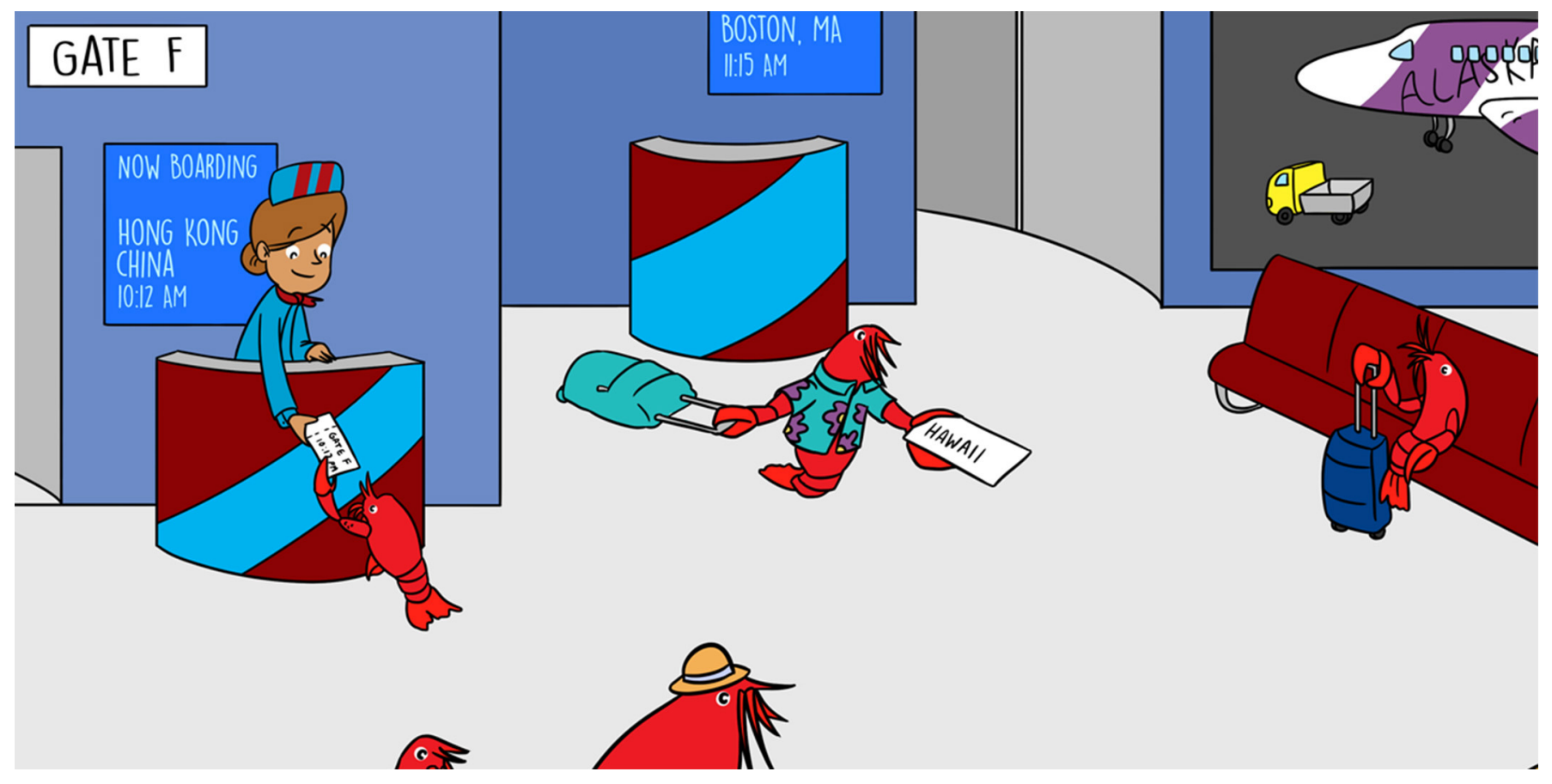

\title{
CONQUERING THE WORLD: THE INVASION OF THE RED SWAMP CRAYFISH
}

\section{Francisco Javier Oficialdegui ${ }^{* t}$}

Department of Wetland Ecology, Doñana Biological Station (EBD-CSIC), Seville, Spain

\section{YOUNG REVIEWERS:}

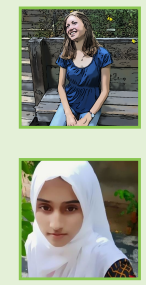

KATI

AGE: 15

SAMEEN

AGE: 14
One of the biggest threats to biodiversity is the invasion of non-native species, also called invasive alien species. It is crucial for scientists to determine the main introduction routes by which non-native species enter into an ecosystem. We studied the red swamp crayfish (Procambarus clarkii), a freshwater crustacean, and looked at the genetic characteristics of 122 crayfish populations (22 native and 100 introduced) to understand their differences and where they came from. Our results showed a great amount of genetic variability among crayfish populations and that, this crayfish species has invaded different parts of the world via multiple introduction events and pathways, with humans playing a key role in these introductions. It is therefore vitally important to control the likely sources of invasion to avoid further introductions and prevent the rapid expansion of crayfish populations. 
NATIVE RANGE

Area where a species has historically lived.

\section{INVASIVE ALIEN}

\section{SPECIES}

Species introduced outside of their original area, which are able to survive, become abundant, spread, and some of them, causing harm to other organisms in their new introduced areas.

\section{WHAT ARE INVASIVE ALIEN SPECIES AND WHY ARE THEY A PROBLEM?}

We live in a changing world, where we can travel over great distances more easily and quickly than ever before. Humans have accidentally, or intentionally, transported lots of species out of their natural homes, or native ranges, for centuries. However, the frequency of such events has drastically increased in recent decades. Many species end up being released into new environments where they can survive, reproduce successfully, and become invasive, which means they begin to outcompete native species [1]. Invasive alien species can cause severe problems for the environment, the economy, and human well-being. For example, the accumulation of zebra mussel (Dreissena polymorpha) shells in water intake pipes used for irrigation of fields can block the pipes and cause the farmers to lose large amounts of money. As another example, the digging activity of a fish called the common carp (Cyprinus carpio) increases the cloudiness of the water, which can reduce the ability of aquatic plants to perform photosynthesis by decreasing the amount of light that reaches them. Given their serious impacts, invasive alien species are considered one of the greatest threats to biodiversity, ecosystem services and human well-being.

Scientists are constantly asking questions about biological invasions. Why are some species successful while others fail? [2]. How are invasive alien species introduced? Why do they become invasive? Where are they distributed? [3]. Researchers know that the invasion process consists of several stages. The success of their establishment often depends on the number of individuals released and how they are introduced. Usually, there is a greater chance of establishment if hundreds of individuals are introduced multiple times into a specific site than if there is one single introduction event involving only a few individuals [4]. Therefore, understanding why these species are introduced, where they came from, how they spread, and how the invasion process works are all key factors in determining the best way to prevent the establishment or spread of invasive alien species and decrease their negative impacts worldwide $[3,5]$.

\section{THE INVASIVE RED SWAMP CRAYFISH (PROCAMBARUS CLARKIII)}

The red swamp crayfish (Procambarus clarkii) is native to the southern United States and north-eastern Mexico, but can now be found in inland waters on all continents except Australia and Antarctica [3]. This freshwater crustacean easily reaches high densities, become an invasive species, and it causes severe ecological and economic impacts, such as preying upon native plants and animals, transmitting diseases to other aquatic species, and damaging dykes and canals in rice fields due to its burrowing activity (Figure 1). But how has the 
Figure 1

A bunch of red swamp crayfish captured in wild (left) and the red swamp crayfish coming out of its burrow made in a dyke of rice field (right).

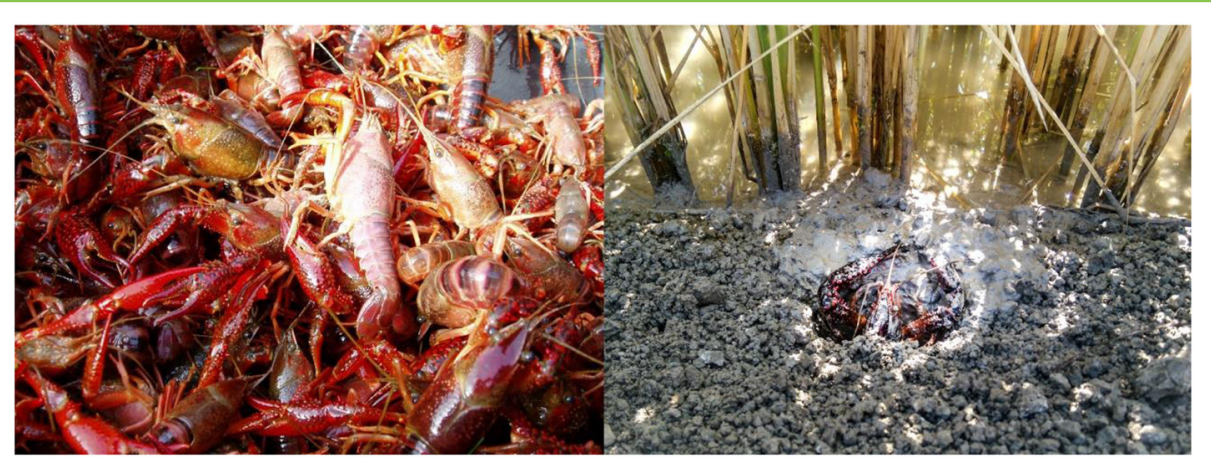

Figure 1

red swamp crayfish become a widespread invader? The introductions of crayfish have mainly been due to its economic value as seafood [3]. Yes! Eating freshwater crayfish is common in many countries (for example, there are Crawfish Festivals in the United States and Sweden) and generates tens of billions of U.S. dollars per year around the world. Due to a lack of awareness of its impacts, and hoping to make some money, people have intentionally introduced this species into the wild in many locations worldwide.

Since the red swamp crayfish has an important commercial value, many introductions to new areas have been well documented by scientists, crayfish enthusiasts, or commercial companies [3]. For example, when crayfish were introduced into Spain, the person who brought them into the country, the precise date and place of introduction, and the number of crayfish introduced were all recorded. However, it is uncommon to have such detailed information, so genetic tools are needed to unravel the invasion history for most invasive species. In the case of the red swamp crayfish, we did both: we used the available historical information and genetic tools to confirm the invasion routes of this organism.

\section{HOW THE RED SWAMP CRAYFISH TOOK OVER THE WORLD}

The first known introductions of the red swamp crayfish into new locations took place in the 1920s: 1924 in California and 1927 in the Hawaiian Islands in United States, 1927 in Japan, and 1929 in China. In the mid-1960s, a batch of crayfish was sent to Uganda and Kenya, and soon afterwards, to other African countries. Simultaneously, these animals spread over Mexico and reached Costa Rica, Puerto Rico, Venezuela, and the Dominican Republic in the 1970s, and Brazil in the mid-1980s. The red swamp crayfish was legally introduced into Spain in 1973 and 1974, first from Louisiana and probably later from Africa or south-east Asia. Currently, this species is present in at least 40 countries worldwide [3]. As you can see, the red swamp crayfish has traveled a lot! By using this information and collecting crayfish 
MITOCHONDRIAL

DNA (mtDNA)

DNA located in the mitochondria, which are cellular organelles within many types of cells.

\section{NUCLEOTIDE}

A molecule that makes up one unit of DNA.

There are four different nucleotides in DNA: adenine (A), cytosine (C), guanine $(\mathrm{G})$, and thymine $(T)$.

\section{HAPLOTYPE}

Sequence of nucleotides in a certain region of the $m t D N A$.

\section{ECOSYSTEM}

Community of living organisms interacting with non-living elements of their environment as a complex system. from different places around the world, we were able to uncover its invasion process, describe its genetic variability, and understand its global invasion patterns.

\section{COLLECTING CRAYFISH THROUGHOUT THE WORLD}

We collected a total of 1,062 red swamp crayfish from 72 locations in North America, East Asia, and Europe. In the laboratory, we isolated a type of DNA that is commonly used to compare populations of animals, called mitochondrial DNA (mtDNA), from a small piece of muscle tissue from each crayfish. We also obtained 354 genetic sequences from crayfish populations in China and Mexico, which had been determined by other researchers, and we compared these with my samples, too. Like all DNA, mtDNA is made up of a string of four molecules, called nucleotides, which are arranged in a specific sequence. DNA sequences are passed down from our parents, and mtDNA sequences always come from our mothers. We selected a short fragment of the mtDNA sequence that we could compare between crayfish locations, to see how genetically similar these animals were. The specific mtDNA sequence of each individual is called its haplotype. Crayfish with the exact same mtDNA sequence are said to have the same haplotype, meaning they are more closely related to each other. If an organism differs by even one nucleotide, it is said to have a different haplotype. So, if two populations of crayfish in different areas of the world (for example, one from China and other from United States) share the same haplotype, there is probably a connection between these two locations, and we can use that genetic connection, together to more technical information, to figure out where the crayfish came from. In this way, we were able to reconstruct the invasion routes of red swamp crayfish around the world.

\section{DIFFERENT INVASION PATTERNS WERE FOUND}

The 1,416 crayfish sequences we studied included 65 different haplotypes, which differed by at least one nucleotide (Figure 2). Generally, in the ecosystem that is native to an organism, we should find all haplotypes, but populations that have been introduced into new non-native environments usually show a smaller number of haplotypes because a few individuals are usually transported. However, the haplotype variability in an invasive species population can vary for a number of reasons, and this is what we found when we looked at the haplotypes of red swamp crayfish.

One thing we learned was that invasive crayfish populations from the western United States had higher haplotype variability and were very different from the invasive populations found in the eastern United States. This is probably because crayfish were introduced multiple times into the western of United States, because there were 
Figure 2

Haplotype sequences of several red swamp crayfish. A fragment of the mtDNA sequence that we selected for comparison is shown at the top of the matrix. The dotted lines underneath represent crayfish sequences from this same location in the DNA. Letters are shown in place of dots in cases where differences in the nucleotide sequence, representing different haplotypes of crayfish, exist. In this picture, different colors represent the four nucleotides of DNA: guanine ( $G$, black), thymine ( $T$, red), adenine ( $A$, green), and cytosine ( $C$, blue). Yellow arrows indicate that the crayfish shown in line numbers 8,13 , and 15 belong to three different haplotypes than do the other 12 crayfish studied.

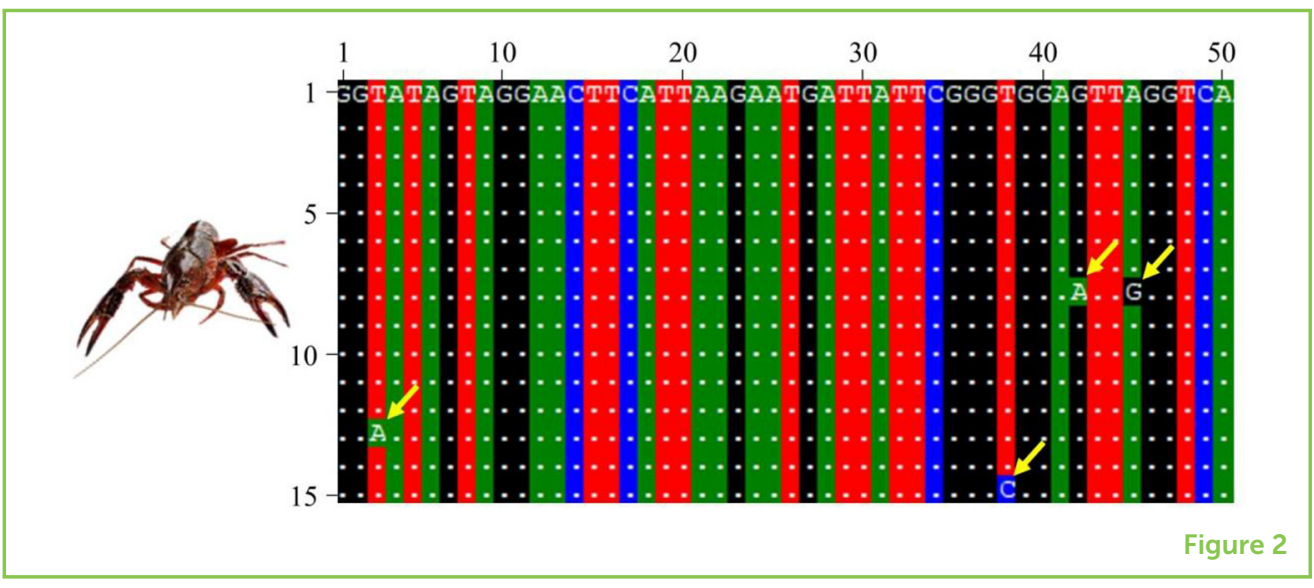

several crayfish supply companies in California that sold live crayfish and end up being released to wild. In the eastern United States, however, a sole company, Carolina Biological Supply Company, was predominant. We also saw low haplotype variability in Asian crayfish populations, which confirmed the invasion history in East Asia. That is, according to the literature, 100 crayfish were carried from New Orleans to Japan in 1927, of which only 20 crayfish survived. In Europe, the highest haplotype variability was found in southern Spain, where the initial introduction of crayfish occurred, and the haplotype variability decreased northwards, as new populations grew from a few individuals transported from the original southern population. However, we found high variability in other European populations, which is probably due to multiple introductions, as explained before. Additionally, we saw a different haplotype in parts of northern Europe, like France, the United Kingdom, Belgium, or The Netherlands, that was not found in southern Spain where the initial introduction occurred. This suggested that other, undescribed introduction routes could have taken place in northern Europe.

\section{TAKE-HOME MESSAGE: CRAYFISH INVASION IS MORE COMPLEX THAN WE THOUGHT}

The red swamp crayfish, just like lots of other invasive species, has been introduced into new locations by humans for many different purposes. Through our work, we described the complex invasion of the red swamp crayfish in the northern hemisphere, highlighting the key role of humans in its movement from one place to another (Figure 3). In recent decades, the red swamp crayfish has been continually introduced in even more locations, which has resulted in its rapid spread all over the globe. Depending on the number of introduction events and the number of individuals introduced, we found invasive populations with low genetic variability (only a few haplotypes) or high genetic variability (multiple haplotypes). Overall, these findings are crucial for understanding how invasive species expand. This knowledge can help us find more effective strategies to 


\section{Figure 3}

Map of the introduction routes of the red swamp crayfish, Procambarus clarkii. The dark gray area shows the native range of the red swamp crayfish. Red circles show areas outside the native range that have been invaded and, subsequently, have become the source of other invasions to additonal locations, also called invasion hubs. The lines/arrows show the introduction routes reported in literature as well as those genetically confirmed in the study (modified from Oficialdegui et al. [6]).

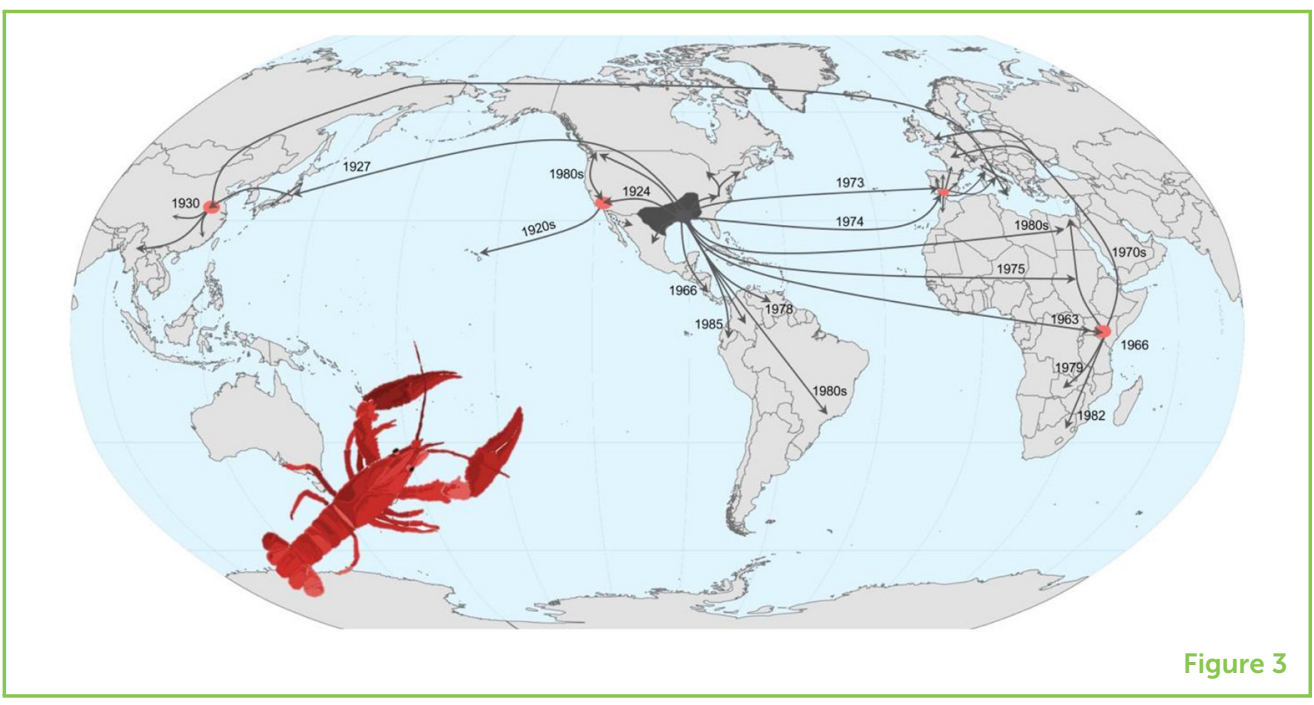

prevent their spread and the negative effects that can result when they take over an ecosystem.

\section{ACKNOWLEDGMENTS}

I am hugely grateful for the comments and suggestions received from T. C. Michot, L. Boyero, M. I. Sánchez, and M. Ferraguti who improved the first draft of the manuscript. I thank the two young reviewers for their comments and suggestions, their two respective mentors and the editors, Pedro Morais and Susan Debad, for their valuable advices to improve this manuscript and making it more suitable to a young audience.

\section{ORIGINAL SOURCE ARTICLE}

Oficialdegui, F. J., Clavero, M., Sánchez, M. I., Green, A. J., Boyero, L., Michot, T. C., et al. 2019. Unravelling the global invasion routes of a worldwide invader, the red swamp crayfish (Procambarus clarkii). Freshw. Biol. 64:1382-400. doi: 10.1111/fwb.13312

\section{REFERENCES}

1. Blackburn, T. M., Pyšek, P., Bacher, S., Carlton, J. T., Duncan, R. P., Jarošík, V., et al. 2011. A proposed unified framework for biological invasions. Trends Ecol. Evol. 26:333-9. doi: 10.1016/j.tree.2011.03.023

2. Babić, I., Hudina, S., and Bielen, A. 2017. Invasion of the Chinese pond mussels-what makes these harmless-looking animals so dangerous? Front. Young Minds 5:56. doi: 10.3389/frym.2017.00056

3. Oficialdegui, F. J., Sánchez, M. I., and Clavero, M. 2020. One century away from home: how the red swamp crayfish took over the world. Rev. Fish Biol. Fisher. 30:121-35. doi: 10.1007/s11160-020-09594-z 
4. Lockwood, J. L., Cassey, P., and Blackburn, T. 2005. The role of propagule pressure in explaining species invasions. Trends Ecol. Evol. 20:223-8. doi: 10.1016/j.tree.2005.02.004

5. Giovos, I., Katsanevakis, S., Coll, M., Piroddi, C., Steenbeek, J., Lasram, F., et al. 2019. Human activities help alien species to invade the Mediterranean Sea. Front. Young Minds 7:97. doi: 10.3389/frym.2019.00097

6. Oficialdegui, F. J., Clavero, M., Sánchez, M. I., Green, A. J., Boyero, L., Michot, T. C., et al. 2019. Unravelling the global invasion routes of a worldwide invader, the red swamp crayfish (Procambarus clarkii). Freshw. Biol. 64:1382-400. doi: 10.1111/fwb.13312

SUBMITTED: 21 October 2019; ACCEPTED: 18 February 2020; PUBLISHED ONLINE: 06 March 2020.

EDITED BY: Pedro Morais, Centre of Marine Sciences, University of Algarve, Portugal

CITATION: Oficialdegui FJ (2020) Conquering the World: The Invasion of the Red Swamp Crayfish. Front. Young Minds 8:26. doi: 10.3389/frym.2020.00026

CONFLICT OF INTEREST: The author declares that the research was conducted in the absence of any commercial or financial relationships that could be construed as a potential conflict of interest.

COPYRIGHT () 2020 Oficialdegui. This is an open-access article distributed under the terms of the Creative Commons Attribution License (CC BY). The use, distribution or reproduction in other forums is permitted, provided the original author(s) and the copyright owner(s) are credited and that the original publication in this journal is cited, in accordance with accepted academic practice. No use, distribution or reproduction is permitted which does not comply with these terms.

\section{YOUNG REVIEWERS}

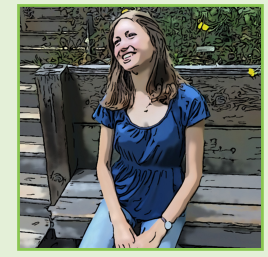

\section{KATI, AGE: 15}

I am a sophomore in high school who enjoys reading and playing the double bass. I love science and am especially interested in animal behavior. I am excited to participate in Frontiers for Young Minds because it enables me to learn new things outside of school as well as share new discoveries with my peers.

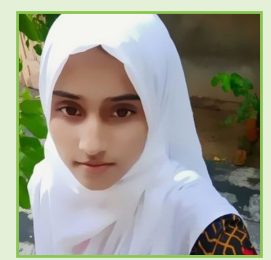

\section{SAMEEN, AGE: 14}

Hello, I am Sameen from Mandi Bahauddin (M.B.Din). My school is very competitive especially in science subjects but I like biology. I like to know about natural processes especially in aquatic species. I love to read newspaper, history books, and learn new languages. Besides, I wish to participate in environmental clubs and field trips. I want to study the ecosystems and biology when I grow up. 


\section{AUTHOR}

\section{FRANCISCO JAVIER OFICIALDEGUI}

My name is Fran and I am a biologist working on the fascinating world of invasive species. I got my Ph.D. at the Doñana Biological Station (EBD-CSIC) in Seville, Spain. My research focuses on how invasive freshwater species become widely distributed and how they succeed once they are introduced. I also study their impacts once they are established out of their native range. In particular, I have mainly studied the red swamp crayfish, a global invader that has been mainly introduced into new locations by humans because of its commercial value, causing severe and devastating impacts on invaded ecosystems afterwards. I enjoy spending time explaining the current problem of biological invasions to the society in general, which I think is a key role for scientists. *oficialdegui@ebd.csic.es; ${ }^{\dagger}$ orcid.org/0000-0001-6223-736X 